\title{
Production of Baby Corn Influenced by Different Dates of Sowing and Planting Geometry
}

\author{
Dibyajiban Panda* and Rinjumoni Dutta \\ Assam Agricultural University, Jorhat-13, India \\ *Corresponding author
}

\section{A B S T R A C T}

\section{Keywords}

Fiber, Planting geometry, Husk, Green fodder, Baby corn, Productivity

Article Info

Accepted:

12 October 2019

Available Online:

10 November 2019
A field experiment was conducted at the Instructional-cum-Research (ICR) Farm, Assam Agricultural University, Jorhat during summer season of 2018 to study the yield attributing characters and yields of baby corn. The experiment was laid out in a split-plot design with three replications. The treatments consisted of four date of sowing viz., $20^{\text {th }}$ February $\left(D_{1}\right), 2^{\text {nd }}$ March $\left(D_{2}\right), 12^{\text {th }}$ March $\left(D_{3}\right), 22^{\text {nd }}$ March $\left(D_{4}\right)$ in main plot and four planting geometry practices viz., $40 \mathrm{~cm}$ x $20 \mathrm{~cm}\left(\mathrm{~S}_{1}\right), 40 \mathrm{~cm}$ x $25 \mathrm{~cm}\left(\mathrm{~S}_{2}\right), 45 \mathrm{~cm}$ x $20 \mathrm{~cm}\left(\mathrm{~S}_{3}\right), 45 \mathrm{~cm} \times 25$ $\mathrm{cm}\left(\mathrm{S}_{4}\right)$, in sub-plot. Results revealed that sowing on $2^{\text {nd }}$ March with planting geometry $40 \mathrm{~cm}$ x $20 \mathrm{~cm}$ resulted in higher growth parameters in terms of plant height and leaf area index. The yield attributing characters like number of cob per plant, weight and length of cob with and without husk and cob girth found maximum in $2^{\text {nd }}$ March sowing with planting geometry of $45 \mathrm{~cm} \times 25 \mathrm{~cm}$. Significantly higher cob yield with and without husk and green fodder yield found in $2^{\text {nd }}$ March sowing with planting geometry of $45 \mathrm{~cm} \times 20 \mathrm{~cm}$ as compared to all the treatments.

\section{Introduction}

Maize (Zea mays L.) is one of the most versatile emerging crops amongst the most imperative cereal, beside wheat and rice on the earth just as in India. Maize is a miracle crop called as "Queen of Cereals" (Kannan, et al., 2013). The cultivation of corn (Zea mays L.) for "baby corn" and grain production is one of the most important activities in the world and especially in Asian countries. Baby corn consists of dehusked ear, harvested two or three days after the emergence of silk. Baby corn is a very high value crop, used as vegetable, which can boost the economy of poor farmers by diversification in their agriculture. Baby corn can be used as a substitute of mushroom. It forms a major use in various salads and soups. The waste portion which is not edible like stem, leaves, fiber etc 
can be fed to cattle as green fodder. Although agronomic requirements of baby corn are similar to normal maize except for the suitable variety, high plant population per unit area, nitrogen requirements and suitable date of sowing which need to be studied for local ago-climatic conditions.

Other than different components date of sowing and plant population per unit area are critical elements deciding yield just as quality of baby corn. Date of sowing is a nonmonetary input which plays significant role in production and productivity of any crop. Different dates of sowing help us to explore the possibility of having more than one crop of baby corn in a growing season. Optimum crop geometry is one of the important factors for higher production leading to efficient utilization of resources and also harvesting as much as solar radiation and in turn better photosynthesis. Optimum crop geometry is one of the important factors for higher productivity, by virtue of which there is efficient utilization of underground resources and also harvesting maximum solar radiation which in turn results in better photosynthesis (Monneveux et al., 2005).Thus, there is need to work out an optimum plant spacing by adjusting inter and intra row spacing in relation to other agronomic factors.

\section{Materials and Methods}

The field experiment was carried out at the Instructional-cum-Research (ICR) Farm, Assam Agricultural University, Jorhat-13 during the summer season, 2018. The site is situated at $26^{\circ} 47^{\prime} \mathrm{N}$ latitude and $94^{\circ} 12^{\prime} \mathrm{E}$ longitude with an altitude of 86.56 meter above the mean sea level. The baby corn variety G-5414 was taken under investigation for assessing its performance under summer season. The site of experiment was well drained and the soil was sandy loam in texture, acidic in reaction, medium in organic carbon $(0.74 \%)$, low in available $\mathrm{N}(232.21$ $\mathrm{kg} / \mathrm{ha}$ ) and medium in available P2O5 (25.36 $\mathrm{kg} / \mathrm{ha})$ and available $\mathrm{K} 2 \mathrm{O}$ (168.72 kg/ha). The treatments consisted of four date of sowing viz., $20^{\text {th }}$ February $\left(\mathrm{D}_{1}\right), 2^{\text {nd }}$ March $\left(\mathrm{D}_{2}\right), 12^{\text {th }}$ March $\left(D_{3}\right), 22^{\text {nd }}$ March $\left(D_{4}\right)$ in main plot and four planting geometry practices viz., $40 \mathrm{~cm} \mathrm{x}$ $20 \mathrm{~cm}\left(\mathrm{~S}_{1}\right), 40 \mathrm{~cm} \times 25 \mathrm{~cm}\left(\mathrm{~S}_{2}\right), 45 \mathrm{~cm} \times 20$ $\mathrm{cm}\left(\mathrm{S}_{3}\right), 45 \mathrm{~cm} \times 25 \mathrm{~cm}\left(\mathrm{~S}_{4}\right)$, in sub-plot with three replication in split-plot design.The experimental field was first ploughed by tractor drawn disc plough and subsequently two harrowings were done followed by levelling. After the preparatory tillage, the field was laid out in 48 plots of same size as per the layout plan and the treatment combinations were applied randomly as per the statistical design. The doses of fertilizers were applied in the plots was 90, 60, 60 of N, $\mathrm{P}, \mathrm{K}$. Full amount of phosphatic (single super phosphate) and potassic (Muriate of potash) fertilizers and half amount of nitrogenous fertilizers (urea) were applied as uniformly as possible before sowing. The rest half of the nitrogenous fertilizer was applied as top dressing during the time of earthing up. Two hand weeding at 25 DAS and 45 DAS were performed. Harvesting of baby corn was done at 2-3 days of silk emergence stage by leaving border rows.

\section{Experimental observations recorded}

From each plot five plants were selected randomly leaving the border rows of the plot and the plant height was measured in centimeters at 25 DAS, 45 DAS and at the harvesting stage from the base of the plant at ground level to the apex of flag leaf. The leaf area was calculated at $25 \mathrm{DAS}, 45 \mathrm{DAS}$ and at harvest by using the formula as given by Lenvill et al., (1978).

Leaf area index (LAI) $=$ Total leaf area/Ground area 
Cobs from five randomly selected plants were counted in each plot and calculated for average value of the number of cobs per plant. Five cobs were selected from each plot and weighed using electric balance very gently and the mean value of the weight of cob with husk as well as without husk was calculated. Average girth of baby corn in each plot was calculated from five randomly selected cobs after harvesting. The width of each selected cobs without husk was measured as diameter and average girth of baby corn without husk was worked out and expressed in $\mathrm{cm}$. Similarly, the length of five randomly selected cobs with husk and without husk from each plot was recorded and the average was worked out.

Cobs were picked up from each plot treatment wise and weighed with and without husk for yield estimation. This was then converted to quintal per hectare. After the picking of cobs, the green plants were allowed to stand in the field for a week. By this time all the plants from net plot were cut close to the ground and the total weight of all plants from each plot was taken. Per plot yields was then converted to quintal per hectare. Then the harvest index can be calculated as the ratio of economic yield to total biological yield and expressed in percentage. The harvest index for baby corn was worked out as indicated below:

Harvest index (\%)

$$
=\frac{\text { Economic yield }(\mathrm{q} / \mathrm{ha})}{\text { Total biological yield }(\mathrm{q} / \mathrm{ha})} \times 100
$$

\section{Statistical analysis}

The data pertaining to various observations were statistically analyzed by the procedure of analysis of variance for split-plot design (SPD) given by Panse and Sukhatma (1985). For significant ' $F$ ' test, critical difference (CD) was reported at 5 per cent probability level.

\section{Results and Discussion}

Effect of date of sowing and planting geometry on the growth parameters of baby corn

The effect of different dates of sowing revealed (Table 1) that there was no significant effect on plant height and leaf area index at 25 DAS. But there is a significant difference in plant height found in 45DAS and at harvest. At 45 DAS and at harvest, sowing on $2^{\text {nd }}$ March has highest plant height which was comparable with sowing on $12^{\text {th }}$ March but significantly higher plant height than sowing on $20^{\text {th }}$ Feb and $22^{\text {nd }}$ March. The higher plant height might be attributed by availability of optimum sunlight, nutrients, space and water by the plants which coupled with favourable climatic conditions especially temperature might have resulted in maximum plant height. These results are in confirmation with the results of Shirzadi (2009), Rahamani et al., (2009) and Zarei et al., (2013) who recorded higher plant height with optimum sowing date. Similarly, at 45 DAS and at harvest, the leaf area index was significantly higher in $2^{\text {nd }}$ March as compared to $20^{\text {th }}$ Feb and $22^{\text {nd }}$ March but statistically at par with $12^{\text {th }}$ March.

This may be due to the availability of favourable condition like sunlight, moisture and nutrients at the particular sowing dates. Lower LAI due to delayed sowing was also recorded by Abayomi and Adedoyin (2009). The different planting geometry practices showed that there was no significant effect of spacing on plant height as well as on leaf area index at 25 DAS but the effects were found to be significant at 45 DAS and at harvest. At 45 DAS and at harvest planting geometry of 40 $\mathrm{cm} \times 20 \mathrm{~cm}$ had significantly higher plant height which was at par with $45 \mathrm{~cm} \times 20 \mathrm{~cm}$ but significantly higher than $45 \mathrm{~cm} \times 25 \mathrm{~cm}$ and $40 \mathrm{~cm}$ x $25 \mathrm{~cm}$ spacing. The higher plant 
height in closer planting geometry might be attributed to increase in competition for sunlight, nutrients, space and water by the plants which coupled with favourable climatic conditions especially temperature might have resulted in maximum plant height. The results are in conformity with the findings of Neelam and Dutta (2018) who also recorded higher plant height with closer planting geometry as compared to wider planting geometry.

\section{Effect of date of sowing and planting geometry on the yield attributes of baby corn}

Yield attributing characters viz., number of cobs per plant, weight and length of cob with husk and without husk, cob girth, varied significantly amongst different sowing dates. It was found that various yield attributing parameters were significantly higher in $2^{\text {nd }}$ March sowing followed by $12^{\text {th }}$ March sowing whereas, lowest value of yield attributes were recorded in $22^{\text {nd }}$ March sowing of baby corn (Table 2). This might be due to the optimum availability of growth resources (light, nutrient, moisture etc.) to the mid sown crop to produce and partition more assimilation to the various sinks for better vegetative growth, leading to producing of higher yield and yield components than the late sown crops. The results of Jaliya et al., (2008) also support the findings. Similarly, significantly higher numbers of cobs per plant were recorded under wider spacing of $45 \mathrm{~cm} \times 25 \mathrm{~cm}$ than the other spacing of $40 \mathrm{~cm} \times 20 \mathrm{~cm}, 45 \mathrm{~cm} \mathrm{x}$ $20 \mathrm{~cm}$ and $40 \mathrm{~cm} \times 25 \mathrm{~cm}$ (Table 2). Increase in number of cobs per plant with increase in spacing i.e. decrease in plant population might be due to minimum competition among the plants for the absorption of water and nutrients from the soil. This finding is in agreement with Gosavi and Bhagat (2009) and Sobhana et al., (2012). Wider spacing of $45 \mathrm{~cm} \times 25 \mathrm{~cm}$ also recorded significantly higher values for girth of baby corn, weight of cob with and without husk and length of cob with and without husk as compared to other spacing of $40 \mathrm{~cm} \mathrm{x} 20 \mathrm{~cm}, 40 \mathrm{~cm} \times 25 \mathrm{~cm}$ and $45 \mathrm{~cm} \mathrm{x}$ $20 \mathrm{~cm}$ (Table 2). Wider spacing provided uniform spread of plants because of less crowding which resulted into healthy cobs and thereby increases the weight, length of cob and girth of baby corn. The results are supported by the findings of Thavaprakaash $e t$ al., (2007) and Neelam and Dutta (2018).

\section{Effect of date of sowing and planting geometry on the yield of baby corn}

Different date of sowing and planting geometry treatments brought out significant effect on the yield of cob with husk, without husk and green fodder (Table 3 and Fig. 1). Yield of the crop is a function of several yield components which are dependent on complementary interaction between vegetative and reproductive growth of the crop. Highest baby corn yield with and without husk, green fodder yield and corn husk ratio were significantly higher in $2^{\text {nd }}$ March planting whereas lowest value was observed in $22^{\text {nd }}$ March planting.

This might be due to the fact that $2^{\text {nd }}$ March planting of baby corn recorded highest value of growth and yield attributes which finally increased the baby corn and green fodder yield (Jaliya et al., 2008). The findings of Tamadon (2000) also revealed that timely sowing of corn resulted in greater partioning of photosynthates from source to sink resulting in higher grain and fodder yield. Similarly, the highest yield of baby corn with and without husk was realized with planting geometry 45 $\mathrm{cm} \times 20 \mathrm{~cm}$. The yield obtained under spacing $45 \mathrm{~cm} \times 20 \mathrm{~cm}$ was statistically at par with 45 $\mathrm{cm} \times 25 \mathrm{~cm}$ but significantly higher than 40 $\mathrm{cm} \times 25 \mathrm{~cm}$ and $40 \mathrm{~cm} \times 20 \mathrm{~cm}$. The lowest yield was associated with spacing $40 \mathrm{~cm}$ x 20 $\mathrm{cm}$. 
Table.1 Effect of date of sowing and planting geometry on plant height and leaf area index of baby corn at 30 DAS, 45DAS and at harvest

\begin{tabular}{|c|c|c|c|c|c|c|}
\hline \multirow[t]{2}{*}{ Treatments } & \multicolumn{3}{|c|}{ Plant height $(\mathbf{c m})$} & \multicolumn{3}{|c|}{ Leaf Area Index } \\
\hline & 30DAS & 45DAS & At harvest & 30DAS & 45DAS & At harvest \\
\hline \multicolumn{7}{|c|}{ Date of sowing (D) } \\
\hline D1 $=20^{\text {th }}$ February & 40.08 & 121.31 & 168.11 & 1.29 & 4.61 & 5.65 \\
\hline D2= $2^{\text {nd }}$ March & 39.47 & 137.85 & 185.03 & 1.39 & 4.84 & 6.00 \\
\hline D3 $=12^{\text {th }}$ March & 39.36 & 129.88 & 177.56 & 1.33 & 4.77 & 5.93 \\
\hline D4=22 ${ }^{\text {nd }}$ March & 37.03 & 119.01 & 166.28 & 1.27 & 4.56 & 5.61 \\
\hline S.Ed( $( \pm)$ & 1.86 & 3.49 & 3.47 & 0.05 & 0.05 & 0.10 \\
\hline $\mathrm{CD}(\mathbf{0 . 0 5})$ & NS & 8.54 & 8.50 & NS & 0.12 & 0.24 \\
\hline \multicolumn{7}{|c|}{ Planting geometry (S) } \\
\hline$S 1=40 \mathrm{~cm} \times 20 \mathrm{~cm}$ & 38.30 & 135.17 & 179.51 & 1.28 & 4.78 & 6.03 \\
\hline$S 2=40 \mathrm{~cm} \times 25 \mathrm{~cm}$ & 37.55 & 121.72 & 170.87 & 1.34 & 4.64 & 5.63 \\
\hline$S 3=45 \mathrm{~cm} \times 20 \mathrm{~cm}$ & 41.78 & 131.87 & 177.06 & 1.30 & 4.75 & 5.95 \\
\hline $\mathrm{S} 4=45 \mathrm{~cm} \times 25 \mathrm{~cm}$ & 38.30 & 119.28 & 169.54 & 1.35 & 4.61 & 5.59 \\
\hline S.Ed $( \pm)$ & 2.23 & 4.91 & 2.91 & 0.04 & 0.04 & 0.14 \\
\hline $\mathrm{CD}(\mathbf{0 . 0 5})$ & NS & 10.13 & 6.00 & NS & 0.07 & 0.29 \\
\hline Interaction & NS & NS & NS & NS & NS & NS \\
\hline
\end{tabular}

Table.2 Effect of date of sowing and planting geometry on number of cobs per plant, weight of cob with husk and weight of cob without husk, length of cob with husk, length of cob without husk and girth of baby corn

\begin{tabular}{|c|c|c|c|c|c|c|}
\hline \multirow[t]{2}{*}{ Treatments } & \multirow{2}{*}{$\begin{array}{c}\text { Number } \\
\text { of cobs } \\
\text { per plant }\end{array}$} & \multicolumn{2}{|c|}{ Weight of cob (g) } & \multirow{2}{*}{$\begin{array}{l}\text { Cob girth } \\
(\mathrm{cm})\end{array}$} & \multicolumn{2}{|c|}{ Cob length $(\mathrm{cm})$} \\
\hline & & With husk & $\begin{array}{c}\text { Without } \\
\text { husk }\end{array}$ & & With husk & $\begin{array}{l}\text { Without } \\
\text { husk }\end{array}$ \\
\hline \multicolumn{7}{|c|}{ Date of sowing (D) } \\
\hline D1 $=20^{\text {th }}$ February & 1.45 & 39.45 & 9.83 & 1.83 & 22.02 & 9.58 \\
\hline D2=2 ${ }^{\text {nd }}$ March & 2.34 & 47.47 & 11.40 & 2.46 & 23.05 & 11.05 \\
\hline D3 $=12^{\text {th }}$ March & 2.20 & 45.18 & 11.16 & 2.29 & 22.99 & 10.39 \\
\hline D4=22 ${ }^{\text {nd }}$ March & 1.18 & 34.06 & 8.81 & 1.41 & 21.13 & 8.83 \\
\hline S.Ed $( \pm)$ & 0.29 & 2.29 & 0.53 & 0.17 & 0.39 & 0.31 \\
\hline $\mathrm{CD}(\mathbf{0 . 0 5})$ & 0.71 & 5.61 & 1.30 & 0.41 & 0.95 & 0.76 \\
\hline \multicolumn{7}{|c|}{ Planting geometry (S) } \\
\hline$S 1=40 \mathrm{~cm} \times 20 \mathrm{~cm}$ & 1.22 & 36.55 & 8.75 & 1.49 & 20.38 & 8.52 \\
\hline $\mathrm{S} 2=40 \mathrm{~cm} \times 25 \mathrm{~cm}$ & 1.92 & 41.70 & 10.99 & 2.17 & 22.83 & 10.33 \\
\hline $\mathrm{S} 3=45 \mathrm{~cm} \times 20 \mathrm{~cm}$ & 1.56 & 41.43 & 9.86 & 1.96 & 22.73 & 10.22 \\
\hline $\mathrm{S} 4=45 \mathrm{~cm} \times 25 \mathrm{~cm}$ & 2.46 & 46.48 & 11.60 & 2.37 & 23.25 & 10.77 \\
\hline S.Ed $( \pm)$ & 0.20 & 2.32 & 0.41 & 0.11 & 0.22 & 0.28 \\
\hline $\mathrm{CD}(0.05)$ & 0.42 & 4.79 & 0.85 & 0.22 & 0.45 & 0.57 \\
\hline Interaction & NS & NS & NS & NS & NS & NS \\
\hline
\end{tabular}


Table.3 Effect of date of sowing and planting geometry on cob yield with husk, cob yield without husk, green fodder yield and harvest index of baby corn

\begin{tabular}{|c|c|c|c|c|}
\hline Treatments & $\begin{array}{l}\text { Cob yield with } \\
\text { husk (q/ha) }\end{array}$ & $\begin{array}{c}\text { Cob yield } \\
\text { without husk } \\
(q / h a)\end{array}$ & $\begin{array}{c}\text { Green fodder } \\
\text { yield (q/ha) }\end{array}$ & Harvest index (\%) \\
\hline \multicolumn{5}{|c|}{ Date of sowing (D) } \\
\hline D1 $=20^{\text {th }}$ February & 65.15 & 12.96 & 250.52 & 4.12 \\
\hline D2= $2^{\text {nd }}$ March & 79.72 & 18.08 & 276.55 & 5.09 \\
\hline D3 $=12^{\text {th }}$ March & 73.94 & 16.34 & 266.45 & 4.83 \\
\hline D4 $=22^{\text {nd }}$ March & 60.55 & 12.29 & 245.84 & 4.02 \\
\hline S.Ed( $( \pm)$ & 2.55 & 1.10 & 6.50 & 0.27 \\
\hline $\mathrm{CD}(0.05)$ & 6.23 & 2.69 & 15.91 & 0.65 \\
\hline \multicolumn{5}{|c|}{ Planting geometry (S) } \\
\hline$S 1=40 \mathrm{~cm} \times 20 \mathrm{~cm}$ & 62.40 & 13.41 & 262.95 & 4.13 \\
\hline $\mathrm{S} 2=40 \mathrm{~cm} \times 25 \mathrm{~cm}$ & 68.48 & 13.70 & 256.72 & 4.20 \\
\hline$S 3=45 \mathrm{~cm} \times 20 \mathrm{~cm}$ & 75.68 & 16.96 & 270.47 & 4.89 \\
\hline $\mathrm{S} 4=45 \mathrm{~cm} \times 25 \mathrm{~cm}$ & 72.80 & 15.60 & 249.21 & 4.84 \\
\hline S.Ed( \pm ) & 3.27 & 1.22 & 6.64 & 0.34 \\
\hline $\mathrm{CD}(0.05)$ & 6.76 & 2.52 & 13.70 & NS \\
\hline Interaction & NS & NS & NS & NS \\
\hline
\end{tabular}

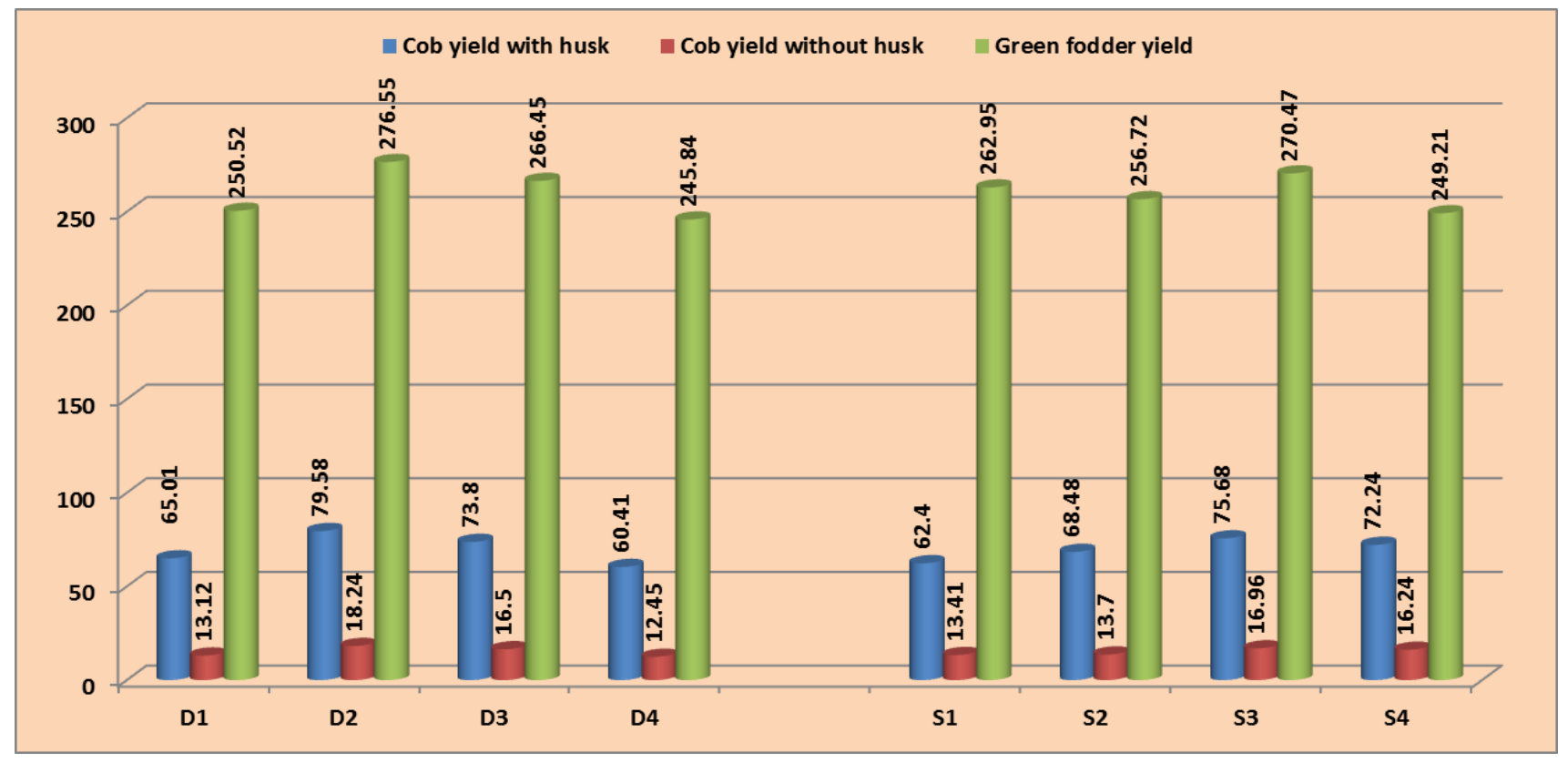


Under wider spacing of $45 \mathrm{~cm} \times 25 \mathrm{~cm}$, all the yield attributing characters were at their best but due of lesser plant population per unit area, it could not compensate the baby corn yield obtained under spacing $45 \mathrm{~cm}$ x $20 \mathrm{~cm}$. Yield of baby corn with husk obtained under $40 \mathrm{~cm} \times 25 \mathrm{~cm}$ was found to be statistically at par with spacing $45 \mathrm{~cm} \times 25 \mathrm{~cm}$. This might be due to more number of plants in spacing 40 $\mathrm{cm} \times 25 \mathrm{~cm}$ as compared to $45 \mathrm{~cm} \times 25 \mathrm{~cm}$. Under $40 \mathrm{~cm}$ x $20 \mathrm{~cm}$ spacing, lower stature of entire yield attributes resulted in the lowest yield of baby corn with husk and without husk. These results are in conformity with the findings of several earlier researchers Arvadiya et al., (2012), Ghosh et al., (2017), Kar et al., (2006) and Neelam and Dutta (2018).

Green fodder yield of baby corn tended to increase with decrease in planting geometry. The planting geometry treatment of $45 \mathrm{~cm} \times 20$ $\mathrm{cm}$ resulted in higher green fodder yield while wider spacing of $45 \mathrm{~cm} \times 25 \mathrm{~cm}$ resulted in lower green fodder yield. The green fodder yield obtained under closer spacing of $40 \mathrm{~cm} \mathrm{x}$ $20 \mathrm{~cm}$ was lower as compared to $45 \mathrm{~cm} \times 20$ $\mathrm{cm}$ but was statistically at par with $45 \mathrm{~cm} \times 20$ $\mathrm{cm}$. It might be because of the increased barrenness under $40 \mathrm{~cm}$ x $20 \mathrm{~cm}$ spacing where supply of growth factors such as light, water and nutrients to plants is affected by interaction between the plants and by the efficiency of use of limiting resources. The possible reason for increased yield under spacing $45 \mathrm{~cm}$ x $20 \mathrm{~cm}$ might be due to optimum number of plants per unit area resulting in higher green fodder yield of baby corn which is comparable with spacing $40 \mathrm{~cm}$ $\mathrm{x} 20 \mathrm{~cm}$. The lower green fodder yield was noticed under $45 \mathrm{~cm}$ x $25 \mathrm{~cm}$ spacing which was due to lesser number of plants per unit area under this planting geometry as compared to rest of the treatments. Similar results regarding the green fodder yield of baby corn were reported by Thakur et al., (1997)., Prodhan et al., (2007), Sukanya et al., (1998), Thakur and Sharma (2000) and Neelam and Dutta (2018) who also envisaged that green fodder yield increased significantly with decrease in spacing i.e. with increase in plant population.

It can be concluded from the above research findings that sowing on $2^{\text {nd }}$ March had a significant effect on the growth, yield attributes, yield and fodder yield of baby corn. Similarly planting geometry of $45 \mathrm{~cm}$ x $20 \mathrm{~cm}$ resulted in higher baby corn as well as green fodder yield. The best performance of baby corn during the summer season could be achieved by sowing the seed on $2^{\text {nd }}$ March with the spacing of $45 \mathrm{~cm} \times 20 \mathrm{~cm}$ with higher productivity.

\section{References}

Abayomi, Y.A. and Adedoyin, G.A. (2009).Effects of planting dates and nitrogen fertilizer application on growth and yield of contrasting genotypes of maize (Zea mays L.) I: Leaf growth and its relationship with grain yield. Journal of Agricultural Research and Development.3: 83-98.

Arvadiya, L.K., Raj, V.C., Patel, T.U. and Arvadiya, M.K. (2012). Influence of plant population and weed management on weed flora and productivity of sweet corn. Indian Journal of Agronomy.57(2): 162167.

Ghosh, M., Maity, S.K., Gupta, S.K. and Chowdhury, A.R. (2017).Performance of baby corn under different plant densities and fertility levels in lateritic soils of Eastern India. Intern. J. Pure App. Biosci. 5(3): 696-702.

Gosavi, S.P. and Bhagat, S.B. (2009).Effect of nitrogen levels and spacing on yield attributes, yield and quality parameters of baby corn (Zea mays). Annual Agricultural Research. 30(3-4): 125-128.

Jaliya, M.M., Mahmud, M. and Sani, Y.A. (2008). Effect of sowing date and NPK fertilizer 
rate on yield and yield components of quality protein maize (Zea mays L.). ARPN Journal of Agricultural and Biological Science. 3(2): 23-29.

Kannan.R.L., Dhivya, M., Abinaya, D., Krishna, R.L. and Kumar, S.K. (2013). Effect of integrated nutrient management on soil fertility and productivity in maize. Bull. Envt.Phamacol. Life Sci. 2(8): 61-67.

Kar, P.P., Barik, K.C., Mahapatra, P.K., Rath, L.M., Bastia, D.K. and Khanda, C.M. (2006). Effect of planting geometry and nitrogen on yield, economics and nitrogen uptake of sweet corn (Zea mays). Indian Journal of Agriculture.51: 43-45

Lenvill, D.E., Dalo, R.F. and Hedgas, H.F. (1978).Solar radiation weighing for weather and corn growth modelsAgronomy for weather and corn growth models.Agron. Trop. 70(2): 257-263.

Monneveux, P., Zaidi, P.H. and Sanchez, C. (2005). Population density and low nitrogen affects yield. Associated Traits in Tropical Maize.Crop Science. 45(2): 103106.

Neelam and Dutta, R. (2018). Production of baby corn as influenced by spacing and nutrient management. Int. J. Curr. Microbiol. App. Sci. 7(12): 1332-1339.

Panse, V.G. and Sukhatma, P.V. (1985). Statistical methods for agricultural workers. ICAR publication, New Delhi, pp. 336-340.

Prodhan, H.S., Bala, S. and Khoyumthem, P. (2007). Response to rate of nitrogen and effect of plant density on yield of baby corn. Journal of Interacademica.11(3): 265-269.

Rahmani, A., KhavariLhorasani, S. and NabaviKalat, S.M. (2009). Effects of sowing date and planting density on morpho-phyisilogical traits, yield and yield components of (baby corn) var. ksc 403su. Journal of Seed and Plant. 25(4): 449-463.
Shirzadi, M.H. (2009). Effects of sowing date on grain development trends in maize hybrids in Jiroft environment. Plant Ecophysiology. 1: 37-41.

Sobhana, V., Kumar, A., Idnani, L.K., Singh, I. and Shivadhar (2012).Plant population and nutrient requirement for baby corn hybrids (Zea mays). Indian Journal of Agronomy. 57(3): 294-296.

Sukanya, T.S., Nanjappa, H.V. and Ramachandrappa, B.K. (1998).Effect of spacings on the growth, development and yield of baby corn (Zea mays L.) varities. Karnataka Journal of Agricultural Sciences.12(1-4): 10-14.

Tamadon, R.M. (2000). Effects of sowing date and plant density, yield and yield components of sweet corn var. KSC403 su in Mazandaranconditions. M.Sc. Thesis of Agronomy, University of Mazandaran, Iran. Pp. 104.

Thakur, D.R. and Sharma, V. (2000). Effect of planting geometry on baby corn yield in hybrid and composite cultivars of maize. Journal of Agricultural Science. 70(4): 246-247.

Thakur, D.R., Prakash, O., Kharawara, P.C. and Bhalla, S.K. (1997). Effect of nitrogen and plant spacing on growth, yield and economics of baby corn (Zea mays). Indian Journal of Agronomy. 43(4): 668671.

Thavaprakash, N. and Velayudham, K. (2007). Effect of crop geometry, intercropping system and INM practices on cob yield and nutrient uptake of baby corn. Asian Journal of Agricultural Research. 1(1): 10-16.

Zarei, M., MasoodSinaki, J., Rahbari, A. and Abaspour, H. (2013). Effects of planting date and salicylic acid on physiological traits of forage maize hybrids. Iranian Journal of Plant Physiology. 3(2): 687693.

\section{How to cite this article:}

Dibyajiban Panda and Rinjumoni Dutta. 2019. Production of Baby Corn Influenced by Different Dates of Sowing and Planting Geometry. Int.J.Curr.Microbiol.App.Sci. 8(11): 13021309. doi: https://doi.org/10.20546/ijcmas.2019.811.153 